\title{
In vitro propagation and cytological analysis of Sophora mollis Royle: an endangered medicinal shrub
}

\author{
Aakriti Bhandari ${ }^{1}$, Harminder Singh ${ }^{1,2}$, Amber Srivastava $^{1}$, Puneet Kumar ${ }^{1}$, G. S. Panwar ${ }^{1 *}$ (D) and A. A. Mao ${ }^{3}$
}

\begin{abstract}
Background: Sophora mollis Royle (family Fabaceae, subfamily-Papilionaceae) is a multipurpose legume distributed in plains and foothills of the North-West Himalaya to Nepal and is facing high risk of extinction due to habitat loss and exploitation by the local people for its fuel and fodder values. Therefore, the present study was conducted to standardize a micropropagation protocol for Sophora mollis by using shoot tip explants and to study the meiotic chromosome count in the species.

Results: Multiple shoots were induced in shoot tip explants of Sophora mollis in Murashige and Skoog medium supplemented with different concentrations of cytokinins alone (BAP, TDZ, and Kinetin) and in combination with varying concentrations of NAA. MS medium supplemented with BAP $(8.9 \mu \mathrm{M})$ was observed to be the optimal medium for multiple shoot induction and maximum 25.32 shoots per explant was obtained with average length of $4.5 \pm 0.8 \mathrm{~cm}$. In vitro developed shoots were transferred onto rooting media supplemented with different concentrations of auxin (IAA, IBA, and NAA). Maximum $86 \%$ rooting was observed in half-strength MS medium supplemented with $21.20 \mu \mathrm{M}$ NAA with an average of 21.26 roots per culture. In vitro raised plantlets were adapted to greenhouse for better acclimatization and $60 \%$ plants were successfully transferred to the open environment. Based on the chromosome counts available from the literature and the current study, the species tend to show a basic chromosome number of $x=9$.

Conclusion: The micropropagation protocol standardized can be helpful for the ex situ mass multiplication and germplasm conservation of the endangered species. Moreover, the ex situ conservation approach will be helpful in actively bridging the gap between ex situ and in situ approaches through the reintroduction of species in the wild. The cytological studies revealed the basic chromosome number $x=9$ of the species.
\end{abstract}

Keywords: Micropropagation, Shoot tip culture, Plant growth regulators, Sophora mollis, Chromosome number

\section{Background}

Sophora mollis (Royle) Baker belongs to family Fabaceae (subfamily-Papilionaceae) is a small deciduous perennial shrub with dense hairy twigs and yellow flowers generally blooms in the month of March to May [1]. It is commonly known as peeli sakina, and distributed to semi-exposed to shaded moist slopes of forest edges

\footnotetext{
* Correspondence: panwar_giriraj@rediffmail.com

'Botanical Survey of India, Northern Regional Centre, Dehradun, Uttarakhand 248195, India

Full list of author information is available at the end of the article
}

in the Western Himalaya at an altitude range of 700-1500 $\mathrm{m}$ in India (Jammu and Kashmir, Himachal Pradesh, and Uttarakhand), Pakistan, Afghanistan, and China [2]. Due to its continuous exploitation from wild habitats by the local people to fulfill their needs, embark it into endangered category as per its conservation status [3].

Previous studies revealed various pharmacological and therapeutic properties of this genera and extensively being used in traditional Chinese drugs since time immemorial. Genus Sophora is a source of more than 300 compounds such as quinolizidine alkaloids (matrine and

\section{Springer Open}

(c) The Author(s). 2021 Open Access This article is licensed under a Creative Commons Attribution 4.0 International License, which permits use, sharing, adaptation, distribution and reproduction in any medium or format, as long as you give appropriate credit to the original author(s) and the source, provide a link to the Creative Commons licence, and indicate if changes were made. The images or other third party material in this article are included in the article's Creative Commons licence, unless indicated otherwise in a credit line to the material. If material is not included in the article's Creative Commons licence and your intended use is not permitted by statutory regulation or exceeds the permitted use, you will need to obtain permission directly from the copyright holder. To view a copy of this licence, visit http://creativecommons.org/licenses/by/4.0/. 
oxymatrine) and flavonoids (prenylated and isoprenylated flavonoids). Phytochemical constituent of genus Sophora is medicinally used as anti-cancerous, antiasthmatic, anti-neoplastic, anti-microbial, anti-pyretic, cardiotonic, anti-inflammatory, diuretic, skin diseases like eczema, colitis, and psoriasis. Besides their curative properties they also have antioxidant properties [4]. Sophora mollis is also a rich source of phytochemical constituents and eight chemical compounds, viz., $(E)$ phytyl epoxide, 7,11,15-trimethyl-3-methylenehexadecane-1,2-diol, loliolide, scopoletin, hexacosanol, octacosanol, $\beta$-sitosterol, and daucosterol have been isolated from the aerial part of it [5].

S. mollis is mainly propagated through seeds and root suckers in the wild but regular cutting of the species for fodder purpose has resulted into poor seed setting and has badly affected the regeneration potential of the species in wild. This might be one of the probable reasons of its population shrinkage from the wild and it is further compounded by various other factors such as habitat degradation, forest fire, and climate change. To overcome the challenges of conventional propagation methods, new advance method of micropropagation is considered as an effective tool for ex situ conservation and its perpetuation in the wild. In vitro morphogenesis seems to be difficult to achieve in the Papilionaceae but with few exceptions; micropropagation protocol were successfully standardized for the Robinia pseudoacacia [6], Pterocarpus indicus [7], and Cassia senna [8], species phylogenetically close to Sophora. In vitro studies were also conducted in some species of Sophora, viz., S. toromiro [9], S. tonkinensis [10], and S. flavescens [11] and in vitro propagation protocol were successfully standardized for them. But best of our knowledge, there is not even a single study on in vitro propagation of $S$. mollis.

S. mollis has a scattered distribution over a wide range from Central Asia to foothills of Western Himalayas and beyond. However, chromosome counts are available from very few regions. Previously meiotic chromosome number $(n=9)$ has been reported in S. mollis from India [12, 13], Iran [14-16], and Russia [17]. Bir and Kumari [12] reported $2 n=18$ in the species from Sangam, Panchmari, Madhya Pradesh, India, with normal meiotic behavior. Noori et al. [15] worked out mitotic chromosome count in the species $(2 n=18)$ with mean chromosome size range between 1.40$2.40 \mu \mathrm{m}$. Advance genomic studies in the genus showed that the species existed at diploid $(2 x)$ level with $2.04 \mathrm{pg}$ genomic size 2C DNA amount [16]. The basic chromosome number varies in the genus Sophora which is a paraphyletic group of species having basic chromosome numbers, i.e., $x=7,8,9,11,14$ [15].

Therefore, this study was undertaken to develop an efficient micro-propagation protocol for the mass multiplication of S. mollis, cytological analysis of the species and to rehabilitate the species in the wild.

\section{Methods}

\section{Initiation of aseptic culture and shoot induction}

The young terminal shoot tip explants $(2.0-3.5 \mathrm{~cm})$ of $S$. mollis were collected from the plants conserved in the Experimental Botanical Garden and identified with the help of herbarium specimen (BSD 123495) for the further in vitro and cytological studies. Explants were initially washed under running tap water for $30 \mathrm{~min}$ followed by Tween-20 (Himedia Laboratories, Mumbai, India) to remove dirt particles, traces of soil, and followed by fungicide treatment ( $1 \%$ bavistin) for disinfection of the explants for $30 \mathrm{~min}$. Thereafter, explants were disinfected with different surface sterilizing agents, i.e., ethanol (70\%), sodium hypochlorite (6\%) (Merck \& Co., USA) and mercuric chloride (0.1\%) (Himedia Laboratories, Mumbai, India) with different time duration of 2, 5, and $8 \mathrm{~min}$, respectively. After each treatment, explants were washed thrice with sterilized double distilled water. Properly disinfected shoot tip explants were further used for the organogenesis experiments. The $\mathrm{pH}$ of the medium was adjusted to 5.7 before autoclaving at $121{ }^{\circ} \mathrm{C}$ for $15 \mathrm{~min}$ and then sterilized shoot tip explants were inoculated onto basal MS medium [18] supplemented with agar $(6 \%)$, sucrose $\left(30 \mathrm{~g} \mathrm{l}^{-1}\right)$, and various PGRs alone or in combinations. Cultures were maintained in the culture room at $24 \pm 2{ }^{\circ} \mathrm{C}$, under a $16 / 8 \mathrm{~h}$ light and dark cycle with a light intensity of $47.29 \mu \mathrm{mol}$ $\mathrm{m}^{-2} \mathrm{~s}^{-1}$ provided by white fluorescent PAR lights (40 W; Wipro, India). All the plant growth regulators (PGRs) applied was procured from Himedia Laboratories, Mumbai, India, and glass wares used (conical flask: Borosil 4980, $250 \mathrm{ml}$, and $85 \times 140 \mathrm{~mm}$; culture tubes: $38 \times 200$ $\mathrm{ml})$ were from Borosil, India.

Explants (size, $1.5-2.0 \mathrm{~cm}$ ) were inoculated onto basal MS medium (control) and MS medium augmented with different concentrations of cytokinins, viz., 6-benzylaminopurine (BAP) $(2.2$ to $11.1 \mu \mathrm{M}), \mathrm{N}$-phenyl-N'-1,2,3-thiadiazol-5-yl urea (thidiazuron/TDZ) (2.27 to $6.8 \mu \mathrm{M})$, and kinetin (2.32 to $9.3 \mu \mathrm{M})$. Subsequently, the optimal concentration of BAP $(8.9 \mu \mathrm{M})$, TDZ $(4.54 \mu \mathrm{M})$, and kinetin $(6.9 \mu \mathrm{M})$ were further tested in combination with different concentrations of naphthalene acetic acid (NAA) $(0.53-2.65 \mu \mathrm{M})$ to observe the synergistic effect of both the PGRs on shoot induction and proliferation.

After shoot initiation, shoot proliferation was performed in MS medium supplemented with BAP (8.9 $\mu \mathrm{M}$ ) having $0.5 \%$ agar (Himedia Laboratories, Mumbai, India). Shoot proliferation cultures were sub-cultured at regular interval of 3 weeks. Shoot multiplication rate was calculated on the basis of percentage of explants 
with positive response, number of total shoots per explant and shoot height after 8 weeks of incubation.

\section{Root induction}

In vitro developed single shoots/shoot cluster of $2-3 \mathrm{~cm}$ length were inoculated onto MS and modified MS medium (half strength and quarter-strength). Further, half-strength MS medium supplemented with different concentrations of auxins, viz., indole-3-acetic acid (IAA) (5.71, 11.42, 17.13, and 22.84 $\mu \mathrm{M})$, indole-3-butyric acid (IBA) $(4.9,7.36,9.8,12.26$, and $14.7 \mu \mathrm{M})$, and naphthalene acetic acid (NAA) $(5.3,10.60,15.90,21.20$, and $23.85 \mu \mathrm{M}$ ) were used for the root development. Cultures were incubated under the same conditions as above and rooting percentage, number of roots and root length were recorded after 6 weeks of incubation.
All the experiments were conducted in triplicates and each set of experiment was carried out with 20 explants. Analysis of variance and mean separation was carried out using Duncan's multiple range tests (DMRT) utilizing the SPS software.

\section{Hardening and transplantation}

Plantlets with properly developed roots were taken out from the culture tubes/flasks after 6-weeks of incubation and washed gently under running tap water to detach the traces of the medium from the roots. Initially to optimize the hardening conditions, the regenerated plantlets were transferred into two set of plastic cups $(8 \times 7 \mathrm{~cm})$, one set was filled with a mixture of soil and sand in equal ratio $(\mathrm{w} / \mathrm{v})$ while another set was containing only sand. All the plantlets were maintained in the green house at $25 \pm 2{ }^{\circ} \mathrm{C}$. Initially to maintain the

Table 1 Effect of cytokinins and NAA on shoot development from shoot tip explants of S. mollis inoculated onto MS medium after 8 weeks of culture

\begin{tabular}{|c|c|c|c|}
\hline Plant growth regulators $(\mu \mathrm{M})$ & Explants with shoots (\%) & No. of shoots per explant (\#) & Shoot length $(\mathrm{cm})(\#)$ \\
\hline \multicolumn{4}{|l|}{$\overline{\mathrm{MS}_{0}}$} \\
\hline \multicolumn{4}{|l|}{ BAP } \\
\hline 2.2 & 68.24 & $10.74 \pm 0.5^{9}$ & $2.5 \pm 0.6^{d}$ \\
\hline 4.4 & 75.81 & $19.22 \pm 0.78^{c}$ & $3.5 \pm 0.5^{\mathrm{bc}}$ \\
\hline 8.9 & 96.27 & $25.32 \pm 0.83^{\mathrm{a}}$ & $4.5 \pm 0.8^{a}$ \\
\hline 11.1 & 66.58 & $20.21 \pm 0.8^{b}$ & $4.2 \pm 0.6^{\mathrm{ab}}$ \\
\hline \multicolumn{4}{|l|}{ TDZ } \\
\hline 2.22 & 54.59 & $13.22 \pm 0.5^{f}$ & $1.5 \pm 0.69^{e}$ \\
\hline 4.54 & 78.69 & $21.54 \pm 0.3^{b}$ & $3.5 \pm 0.4^{\mathrm{bc}}$ \\
\hline 6.81 & 65.38 & $17.21 \pm 0.29^{c d}$ & $2.7 \pm 0.8^{d}$ \\
\hline \multicolumn{4}{|l|}{ Kinetin } \\
\hline 2.32 & 53.87 & $11.15 \pm 0.3^{9}$ & $2.5 \pm 0.78^{d}$ \\
\hline 4.6 & 68.18 & $18.69 \pm 0.28^{c d}$ & $3.5 \pm 0.42^{\mathrm{bc}}$ \\
\hline 6.9 & 76.78 & $19.86 \pm 0.36^{c}$ & $4.3 \pm 0.2^{\mathrm{a}}$ \\
\hline 9.3 & 70.09 & $17.85 \pm 0.3^{\mathrm{cd}}$ & $4.1 \pm 0.39^{\mathrm{ab}}$ \\
\hline \multicolumn{4}{|l|}{$\mathrm{BAP}+\mathrm{NAA}$} \\
\hline $8.9+0.53$ & 85.98 & $25.26 \pm 0.39^{a}$ & $4.1 \pm 0.68^{\mathrm{ab}}$ \\
\hline $8.9+1.59$ & 82.21 & $22.68 \pm 1.3^{b}$ & $3.9 \pm 0.7^{b}$ \\
\hline $8.9+2.65$ & 80.23 & $18.26 \pm 0.4^{\mathrm{cd}}$ & $3.9 \pm 0.6^{b}$ \\
\hline \multicolumn{4}{|l|}{ TDZ+NAA } \\
\hline $4.5+0.53$ & 78.65 & $20.21 \pm 0.31^{c}$ & $2.5 \pm 0.46^{d}$ \\
\hline $4.5+1.59$ & 72.34 & $18.96 \pm 0.42^{c d}$ & $2.4 \pm 0.4^{d}$ \\
\hline $4.5+2.65$ & 69.23 & $16.17 \pm 0.47^{\mathrm{de}}$ & $2.4 \pm 0.41^{d}$ \\
\hline \multicolumn{4}{|l|}{ Kinetin + NAA } \\
\hline $6.9+0.53$ & 76.16 & $19.21 \pm 0.71^{\complement}$ & $4.0 \pm 0.8^{\mathrm{ab}}$ \\
\hline $6.9+1.59$ & 74.25 & $17.11 \pm 0.29^{c d}$ & $3.9 \pm 0.7^{b}$ \\
\hline $6.9+2.65$ & 68.95 & $13.24 \pm 0.2^{f}$ & $3.9 \pm 0.9^{b}$ \\
\hline
\end{tabular}

\#Data are presented as the mean \pm SD $(n=20)$ 
humidity, plants were covered with transparent polythene sheet and removed after 1 week. After 2 months, plantlets were shifted to nursery black polybags $(4.5 \times 8$ inch) containing soil and maintained in the poly house. Plantlets were provided half-strength modified Hoagland solution [19] at 3 days interval. In order to acclimatize plants to field conditions, plantlets were transferred to poly bags containing compost enriched soil after 4 weeks and maintained in the open.

\section{Meiotic studies}

For chromosome counts and male meiosis, suitablesized floral buds were fixed in Carnoy's fluid (absolute alcohol: chloroform: glacial acetic acid in a ratio of 6:3:1 $(\mathrm{v} / \mathrm{v}))$. Samples (BSD 123495) for the study were collected from the plant conserved in the Experimental Botanical Garden. Young and emerging anthers from unopened buds were squashed in 1\% acetocarmine and meiotic preparations were made. In each case, 50-100 meiocytes were observed under light microscope at different stages of meiosis for chromosome counts and detailed meiotic course. For microsporogenesis, 100-200 sporads were analyzed in each case. Pollen fertility was assessed through stainability tests by crushing the completely developed anthers in glycerol-acetocarmine mixture (1:1). Well-filled pollen grains with totally stained

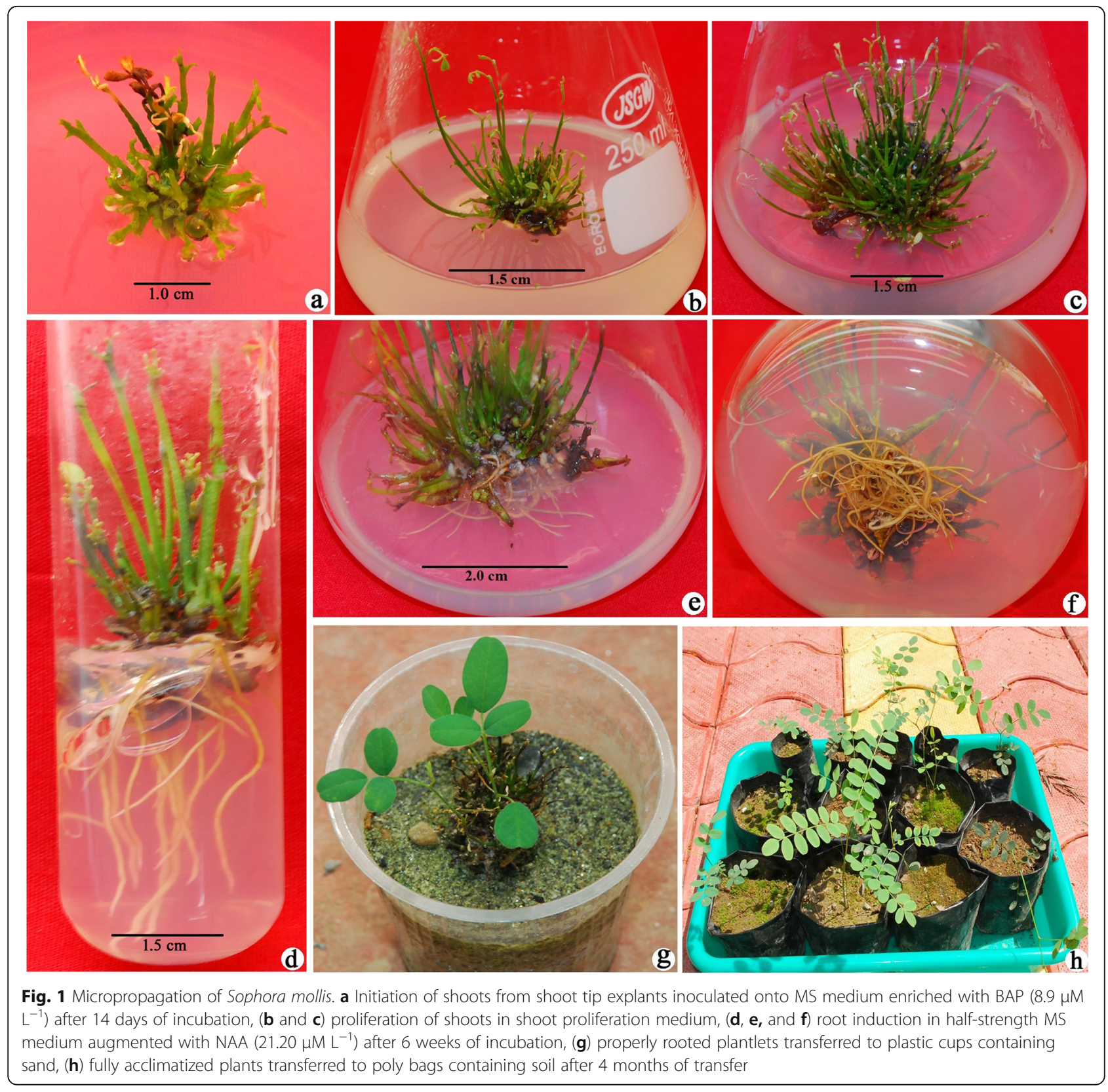


cytoplasm and nuclei were counted as fertile whereas shriveled and those with stainless/incompletely stained cytoplasm were noted as sterile. Photomicrographs of meiocytes, sporads, and pollen grains were taken from temporary preparations using Nikon microscope fitted with a digital camera.

\section{Results}

\section{Shoot induction and proliferation}

The excised shoot tip explants inoculated onto the shoot initiation basal MS medium (control) did not show any morphogenic response. When basal media was enriched with BAP (2.2 to $11.1 \mu \mathrm{M})$, TDZ (2.27 to $6.8 \mu \mathrm{M})$, and kinetin (2.32 to $9.3 \mu \mathrm{M})$, a significant increase was observed in shoot formation percentage and maximum 96.27\% shoot development was observed in BAP substituted medium followed by TDZ $(78.69 \%)$ and kinetin $(76.78 \%)$ (Table 1). Since BAP $(8.9 \mu \mathrm{M})$, TDZ (4.54 $\mu \mathrm{M})$, and kinetin $(6.9 \mu \mathrm{M})$ yielded the maximum shoot proliferation rate in the MS medium, they were further tested in combination with various concentrations of NAA $(0.53-2.65 \mu \mathrm{M})$. But no significant difference was observed in the shoot proliferation rate, besides shoot formation, callusing was also observed and consequently a reduction in the number of shoots. Based on all the experiments, MS medium supplemented with $8.9 \mu \mathrm{M}$ BAP was considered optimal for the shoot development and a maximum of $96.27 \%$ shoot formation was achieved with 25.32 mean shoot number per culture and $4.5 \mathrm{~cm}$ shoot length (Fig. 1a-c).

\section{Root induction}

Tufts of healthy shoots $(4.0 \mathrm{~cm}$ height $)$ were shifted for the root induction onto basal MS and modified MS medium (half and quarter strength). Shoots transferred to basal MS medium did not yield any rooting response, while 10.14 and $7.32 \%$ rooting was observed in the half and quarter-strength MS medium, respectively. Since half-strength MS medium yielded better rooting response, further experiments were conducted in the half-strength MS medium. By incorporation of IBA (4.9-14.7 $\mu \mathrm{M})$, NAA $(5.3-23.85 \mu \mathrm{M})$ and IAA (5.71-22.84 $\mu \mathrm{M}$ ) into half-strength MS medium, a significant increase was observed in the rooting percentage. Maximum rooting rates of 86.3, 39.45, and $37.29 \%$ were observed in NAA, IBA, and IAA augmented half-strength MS medium (Table 2). The halfstrength MS medium, augmented with NAA (21.2 $\mu \mathrm{M})$ was found to be the optimal for root development in S. mollis and $86.3 \%$ rooting was achieved with average 21.26 numbers of roots per shoot after 6-weeks of incubation (Fig. 1d-f).
Table 2 Effect of auxins on root induction in in vitro regenerated shoots of $S$. mollis in half-strength MS medium after 6 weeks of culture

\begin{tabular}{|c|c|c|c|c|c|}
\hline \multicolumn{3}{|c|}{ Auxins $(\mu \mathrm{M})$} & \multirow{2}{*}{$\begin{array}{l}\text { Rooting } \\
\text { (\%) }\end{array}$} & \multirow{2}{*}{$\begin{array}{l}\text { No. of roots } \\
\text { per shoot (\#) }\end{array}$} & \multirow{2}{*}{$\begin{array}{l}\text { Root } \\
\text { length } \\
\text { (cm) (\#) }\end{array}$} \\
\hline IBA & NAA & IAA & & & \\
\hline $1 / 2 \mathrm{MS}$ & 0 & 0 & 10.14 & $1.9 \pm 0.39^{j}$ & $0.5 \pm 0.2^{9}$ \\
\hline 4.9 & 0 & 0 & 18.11 & $4.9 \pm 0.87^{i}$ & $1.5 \pm 0.29^{f}$ \\
\hline 7.36 & 0 & 0 & 21.32 & $7.96 \pm 0.41^{\mathrm{fg}}$ & $2.7 \pm 0.3^{c}$ \\
\hline 9.8 & 0 & 0 & 27.21 & $8.85 \pm 0.7^{f}$ & $2.8 \pm 0.27^{c}$ \\
\hline 12.26 & 0 & & 39.45 & $12.08 \pm 0.71^{d}$ & $3.1 \pm 0.4^{b}$ \\
\hline 14.7 & 0 & & 33.19 & $10.30 \pm 0.9^{e}$ & $3.0 \pm 0.3^{b}$ \\
\hline 0 & 5.3 & 0 & 28.89 & $12.15 \pm 0.81^{d}$ & $1.5 \pm 0.49^{f}$ \\
\hline 0 & 10.60 & 0 & 55.28 & $15.33 \pm 0.62^{c}$ & $2.0 \pm 0.4^{\mathrm{e}}$ \\
\hline 0 & 15.90 & 0 & 75.38 & $18.54 \pm 1.0^{b}$ & $4.2 \pm 0.82^{a}$ \\
\hline 0 & 21.20 & 0 & 86.30 & $21.26 \pm 1.2^{\mathrm{a}}$ & $4.5 \pm 0.9^{\mathrm{a}}$ \\
\hline 0 & 23.85 & 0 & 80.18 & $19.10 \pm 0.92^{b}$ & $4.3 \pm 0.9^{a}$ \\
\hline 0 & 0 & 5.71 & 17.24 & $5.69 \pm 0.42^{h}$ & $1.6 \pm 0.28^{f}$ \\
\hline 0 & 0 & 11.42 & 23.54 & $8.14 \pm 0.69^{f}$ & $2.5 \pm 0.35^{\mathrm{cd}}$ \\
\hline 0 & 0 & 17.13 & 37.29 & $11.23 \pm 0.29^{\mathrm{de}}$ & $2.9 \pm 0.4^{b}$ \\
\hline 0 & 0 & 22.84 & 31.12 & $10.21 \pm 0.5^{\mathrm{e}}$ & $2.7 \pm 0.39^{c}$ \\
\hline
\end{tabular}

\#Data are presented as the mean \pm SD $(n=20)$

Means followed by different letter within columns indicate significant differences at $p \leq 0.05$

\section{Hardening and transplantation}

To optimize the hardening conditions, initially twenty plantlets each, with well-developed roots, were shifted to plastic cups containing a mixture of soil and sand in 1:1 ratio (w/v) and sand only (Fig. 1g). All the plantlets were kept inside the greenhouse to adapt to open environment for 1 month. Plantlets shifted to sand responded better and after 2 months plants were shifted to nursery black poly bags containing compost enriched soil in the greenhouse. Fully acclimatized plants were finally transferred to the open environment with $60 \%$ success (Fig. $1 \mathrm{~h}$ ), and plants were also transferred to suitable wild habitats under the habitat rehabilitation and species recovery program.

\section{Meiotic studies}

Meiotic chromosome number of $n=9$ was determined in S. mollis by the presence of 9:9 chromosomes distributions at metaphase-II (Fig. 2a). In very few instances, lagging chromosomes and non-disjunction of chromatin material was observed (Fig. 2b, c). Majority of the pollen mother cells showed normal pairing of chromosomes and equal segregation at anaphase. Consequently, hundred percent pollen fertility was recorded (Fig. 2d).

\section{Discussion}

S. mollis is a small deciduous perennial shrub with distinct therapeutic properties and used in traditional 


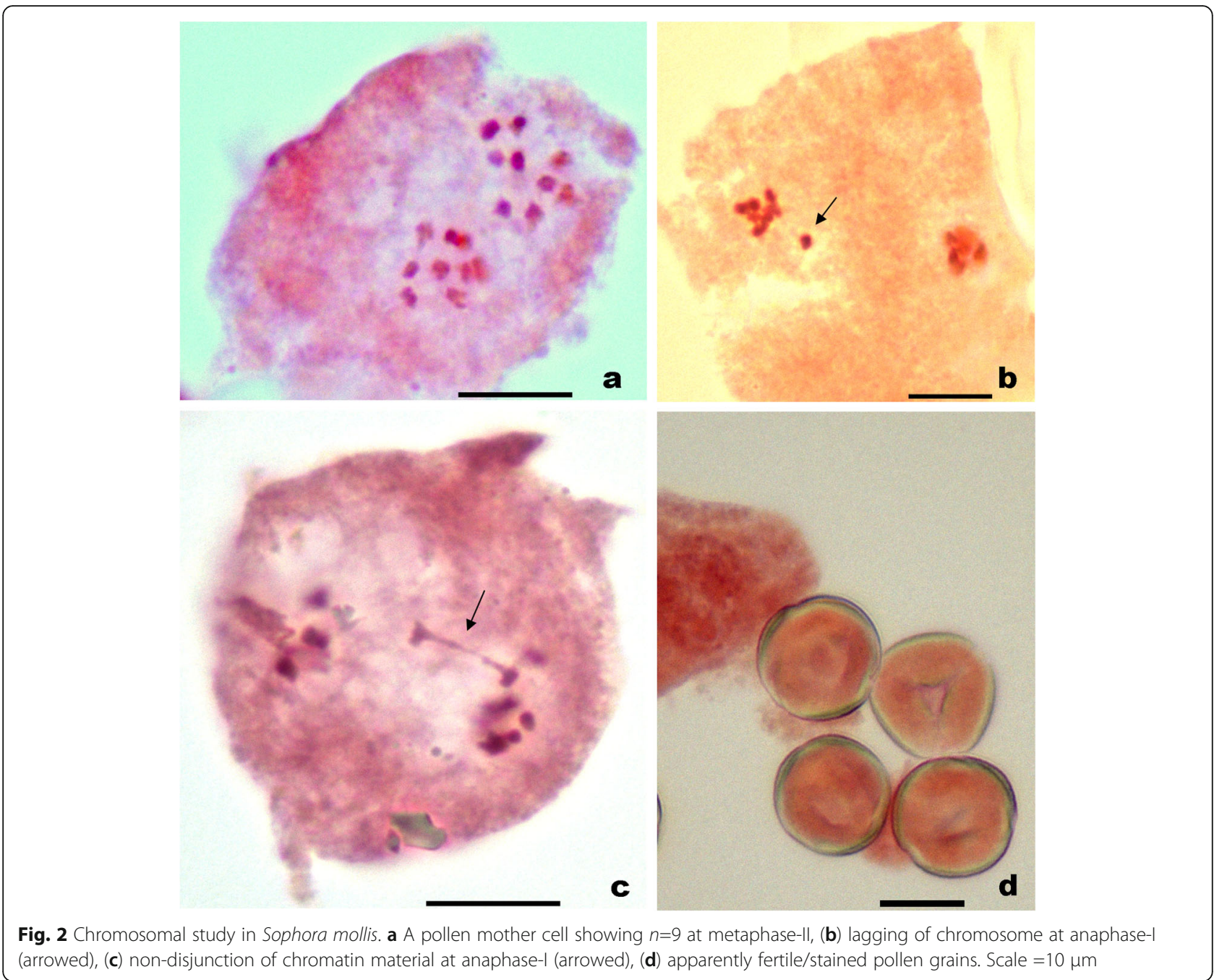

Chinese drugs since time immemorial. The unsustainable overexploitation has resulted into the dwindling population size of species in the wild. Thus, plant propagation through tissue culture is recognized as a viable alternative for the multiplication, conservation, and utilization of threatened taxa [20,21]. Reintroduction of plants into their native environment, under the species recovery and habitat rehabilitation programs, is becoming an increasingly utilized strategy in threatened plant conservation and also proven successful in a variety of species $[22,23]$.

The in vitro study on $S$. mollis revealed that the MS medium enriched with $8.9 \mu \mathrm{M}$ BAP was observed to be optimal for the development of shoots and maximum $96.27 \%$ shoot formation was achieved with $25.32 \pm 0.83$ mean shoot number per culture and $4.5 \pm 0.8 \mathrm{~cm}$ shoot length, respectively. The current finding is in accordance to the previous reports on Sophora tonkinensis [24] in which shoot development was observed in MS medium fortified with 2ip $\left(2.0 \mu \mathrm{M} \mathrm{l}^{-1}\right)$ and 5.0 shoots per culture was obtained. While contrary to this, shoot development was also achieved in combination of BAP and auxin (NAA, IBA, and IAA) in S. tonkinensis [10], S. flavescens [11] and S. toromiro [9]. Explants inoculated onto MS medium enriched with TDZ and NAA, exhibit hyperhydricity in shoots, thus reducing the total shoot number, and similar phenomenon was also reported in S. flavescens [11]. Among all the cytokinins used, BAP alone proved to be the most optimal and maximum shoot formation (25.32) was achieved.

Half-strength MS medium augmented with NAA $(21.2 \mu \mathrm{M})$ was found to be the optimal for root development in $S$. mollis. Maximum $21.26 \pm 1.2$ roots per shoot were observed with average root length of $4.5 \mathrm{~cm}$ after 6 -weeks of incubation. NAA was also the most appropriate for root induction in S. flavescens [11]. All the in vitro raised plantlets were successfully hardened with $60 \%$ of success and were finally transferred to the open environment. Well established plants planted to the wild habitat, under the Habitat 
Rehabilitation and Species Recovery Program, were also growing successfully and $80 \%$ survival rate was reported after 6 months of transfer.

The meiotic chromosome analysis of $S$. mollis exhibit a basic chromosome number of $x=9$, which is in accordance to previous studies on the species [12-15, 17]. This is the first report of chromosome count in the species from Indian Himalayan region. The species occurred at diploid level $(2 x=18$, with base chromosome number $x=9$ ) as per the current study. Further, the meiotic course in the species was found to be normal with hundred percent pollen fertility.

\section{Conclusion}

In conclusion, the current investigation first time describes an efficient and reproducible micropropagation protocol for the Sophora mollis, a threatened multipurpose species of the North-West Himalaya. This micropropagation system assured effective establishment, mass multiplication, and could offer an in vitro strategy for the ex situ conservation of this threatened shrub. This is the first report of chromosome count in S. mollis from Indian Himalayan region and revealed the basic chromosome number $x=9$.

\section{Abbreviations}

BAP: 6-Benzylaminopurine; NAA: Naphthalene acetic acid; IBA: Indole butyric acid; IAA: Indole acetic acid; TDZ: N-Phenyl-N0-1,2,3-thiadiazol-5-urea or thidiazuron

\section{Acknowledgements}

Authors are thankful to the Head of office, Botanical Survey of India, Northern Regional Centre, Dehradun, for providing the necessary facilities. Authors are also thankful to G.B. Pant National Institute of Himalayan Environment and Sustainable Development (GBPNIHESD) under the National Mission on Himalayan Studies (NMHS) (GBPNI/NMHS-2017-18/LG-03/570; dated-26/02/2018) for the financial assistance.

\section{Authors' contributions}

$A B$ conducted the in vitro experiments, AS surveyed the locality of the species in the wild and collected the explant material, HS and PK conducted the cytological studies, GSP recorded the data of tissue culture experiments and prepared the final manuscript and AAM has supervised the overall work. All the authors have read and approved the manuscript.

\section{Funding}

This study was financially supported by the G. B. Pant National Institute of Himalayan Environment and Sustainable Development, Ministry of Environment, Forests and Climate Change, Government of India, under the National Mission on Himalayan Studies (NMHS).

Availability of data and materials

Not applicable

\section{Declarations}

Ethics approval and consent to participate

Not applicable

\section{Consent for publication}

Not applicable

\section{Competing interests}

The authors declare that they have no competing interests.

\section{Author details}

${ }^{1}$ Botanical Survey of India, Northern Regional Centre, Dehradun, Uttarakhand 248195, India. ${ }^{2}$ Botanical Survey of India, Eastern Regional Centre, Shillong, Meghalaya 793003, India. ${ }^{3}$ Botanical Survey of India, Kolkata, West Bengal, India.

Received: 14 January 2021 Accepted: 5 March 2021

Published online: 15 March 2021

\section{References}

1. Manzoor M, Manzoor M, Bibi S, Zaibunisa (2013) Antibacterial activity of Sophora mollis against Escherichia coli and phytochemical tests of plant. ARPN J Agric Biol Sci 8(7):525-530

2. Srivastava A, Srivastava SK, Dangwal LR (2016) Specific habitat requirement and ex-situ conservation of some threatened plant species of Western Himalaya. Int J Environ Biodivers 7(4):179-184

3. Mamgain SK (1999) Phenological observation and conservation of Sophora mollis Royle (Papilionaceae) an endangered multi-purpose legume of NorthWest Himalaya. Taiwania 44(1):137-144

4. Krishna PM, Rao KNV, Sandhya S, Banji D (2012) A review on phytochemical, ethnomedical and pharmacological studies on genus Sophora, Fabaceae. Brazilian J Pharmacognosy 22(5):1145-1154. https://doi.org/10.1590/S0102$695 \times 2012005000043$

5. Fei DQ, Arfan M, Rafiq J, Gao K (2009) Chemical constituent from the aerial parts of Sophora mollis. Chem Nat Compounds 45(6):896-897. https://doi. org/10.1007/s10600-010-9477-9

6. Brown CL, Sommer HE (1982) Vegetative propagation of dicotyledonous trees. In: Bonga JM, Durzan DJ (eds) Tissue Culture in Forestry, Forestry Sciences, vol 5. Springer, Dordrecht, pp 109-149. https://doi.org/10.1007/ 978-94-017-3538-4_5

7. Rao AN, Lee SK (1982) Importance of tissue culture in tree propagation. In: Fujiwara A (ed) Proc. 5th Intl. Cong. Plant Tissue \& Cell Culture. Maruzen Co., Tokyo, pp 715-718

8. Rai PP, Turtle TD, Greenmith SL (1974) Anthracene derivatives in tissue culture of Cassia senna L. J Pharm Pharmacol 26(9):722-726. https://doi. org/10.1111/j.2042-7158.1974.tb09356.x

9. Iturriaga L, Jordan M, Roveraro C, Goreux A (1994) In vitro culture of Sophora toromiro (Papilionaceae), an endangered species. Plant Cell Tiss Organ Cult 37(2):201-204. https://doi.org/10.1007/BF00043617

10. Kun-Hua W, Lin-Xuan L, Yong-Cai H, Mei-Ying W, Cui J-HM (2013) Tissue culture of Sophora tonkinensis Gapnep. and its quality evaluation. Pharmacogn Mag 9(36):323-330. https://doi.org/10.4103/0973-1296.117828

11. Zhao DL, Guo GQ, Wang XY, Zheng GC (2003) In vitro micropropagation of a medicinal plant species Sophora flavescens. Biol Plant 47:117-120

12. Bir SS, Kumari S (1973) In IOPB chromosome number reports XLI. Taxon 22: 459-464

13. Kumari S, Bir SS (1990) Karyomorphological evolution in Papilionaceae. J Cytol Genetics 25:173-219

14. Aryavand A (1975) Contribution a l'etude cytotaxonomique de quelques angiospermes de I'Iran (Contribution to the cytotaxonomic study of some angiosperms from Iran). Botaniska Notiser 128:299-311

15. Noori M, Simmonds MSJ, Ingrouille M (2001) Chromosome studies of Iranian members of tribe Sophoreae (family Leguminosae). J Sci Islamic Republic Iran 12:111-116

16. Ohri D, Bhargava A, Chatterjee A (2004) Nuclear DNA amounts in 112 species of tropical hardwoods - New estimates. Plant Biol 6(5):555-561. https://doi.org/10.1055/s-2004-821235

17. Zemskova EA (1990) In: Takhtajan A (ed) Numeri Chromosomatum Magnoliophytorum Florae URSS, Aceraceae - Menyanthaceae. Leninopoli, Nauka

18. Murashige T, Skoog F (1962) A revised medium for rapid growth and bioassays with tobacco tissue cultures. Physiol Plant 15(3):473-497. https:// doi.org/10.1111/j.1399-3054.1962.tb08052.x

19. Epstein E (1972) Mineral nutrition of plants: principles and perspectives. John Wiley, New York, p 412

20. Wochok ZS (1981) The role of tissue culture in preserving threatened and endangered plant species. Biol Conserv 20(2):83-89. https://doi.org/10.1016/ 0006-3207(81)90019-7

21. Fay MF (1994) In what situations is in vitro culture appropriate to plant conservations? Biodivers Conserv 3(2):176-183. https://doi.org/10.1007/ BF02291887 
22. Maunder M (1992) Plant reintroduction: an overview. Biodivers Conserv 1: 51-62

23. Stewart SL (2008) Orchid reintroduction in the United States: a minireview. NANOJ 14:54-59

24. Jana S, Sivanesar JBR (2013) Effects of cytokinins on in vitro multiplication of Sophora tonkinensis. Asian Pacific J Trop Biomed 3(7):549-553. https://doi. org/10.1016/\$2221-1691(13)60111-2

\section{Publisher's Note}

Springer Nature remains neutral with regard to jurisdictional claims in published maps and institutional affiliations.

Submit your manuscript to a SpringerOpen ${ }^{\circ}$ journal and benefit from:

- Convenient online submission

- Rigorous peer review

- Open access: articles freely available online

High visibility within the field

- Retaining the copyright to your article

Submit your next manuscript at $\boldsymbol{\sim}$ springeropen.com 